\title{
EXAMINING THE DETERMINANT FACTORS ON CONSUMER SWITCHING INTENTION TOWARD ISLAMIC BANK IN CENTRAL JAVA, INDONESIA
}

\author{
Sulis Riptiono $^{1^{*}}$, Agus Suroso $^{2}$, Ade Irma Anggraeni ${ }^{3}$ \\ ${ }^{1} \mathrm{PhD}$ Student, Universitas Jenderal Soedirman, Indonesia and Lecturer STIE Putra Bangsa, Indonesia, ${ }^{2}$ Professor, \\ Universitas Jenderal Soedirman, Indonesia, ${ }^{3}$ Associate Professor, Universitas Jenderal Soedirman, Indonesia. \\ Email: ${ }^{1 *}$ sulis.riptiono@gmail.com, ${ }^{2}$ roso.fe2014@gmail.com, ${ }^{3}$ ade.anggraeni.gardjito@gmail.com
} Article History: Received on $20^{\text {th }}$ February 2020, Revised on $24^{\text {th }}$ March 2020, Published on $01^{\text {st }}$ April 2020

\begin{abstract}
Purpose of the study: The purpose of this paper is to examine the determinant factors that influence consumer switching intentions from conventional banks to Islamic banks in Central Java, Indonesia.

Methodology: This study is quantitative research in which data is collected by using a survey with the questionnaire. Data was collected by distributing questionnaires to 480 Muslim respondents who were still registered as customers at three conventional government banks in Indonesia using purposive sampling techniques and analyzed with SEM-AMOS v24.

Main Findings: The result showed that all out of the hypotheses tested, there is only one hypothesis that was rejected, is the fourth hypothesis. This research reveals that consumer trust in Islamic banks, consumer awareness and religiosity had a positive and significant effect on attitude toward Islamic banks. Furthermore, consumer awareness and religiosity are also able to predict consumer switching intentions at Islamic banks but consumer trust toward Islamic banks has insignificant consumer switching intentions at Islamic banks.
\end{abstract}

Applications of this study: Based on the results of the study, conventional bank consumers' intentions to switch to Islamic banks are influenced by consumer awareness, level of religiosity, and consumer attitudes toward Islamic banks. Furthermore, this is becoming a very important concern for Islamic banks to pay more attention to the antecedents used in this study. Trust is an important predictor for companies in increasing intentions, in this study then it has not been proven to influence consumer intentions to move to Islamic banks. Trust will be able to increase intention if consumers have a good attitude towards Islamic banks.

Novelty/Originality of this study: This study linked the variables of consumer awareness, religiosity, consumer trust, attitudes toward Islamic banks and consumer switching intentions on Islamic banks within a conceptual framework.

Keywords: Islamic Bank, Consumer Awareness, Consumer Trust, Religiosity, Attitudes toward Islamic Bank, Consumer Switching Intention.

\section{INTRODUCTION}

The increasing competition between the conventional banking industry and Islamic banking, targeting the same customer segment both Muslim and non-Muslim. Islamic banks and conventional banks are truly significant difference, the conventional banks apply the interest system while Islamic banks assume that interest is riba and is prohibited in Islam (Sayani \& Miniaoui, 2013). Riba is income from customer loans received in advance or referred to as interest in conventional bank terms (Belwal \& Al Maqbali, 2018). Islamic banks forbid the practice of riba and do not provide savings or loan interest to customers because all transactions are carried out based on the distribution of profits and losses between the bank and the customer. Islamic Banking serves not only Muslim customers but also serves nonMuslim customers (Saleh et al., 2017). This encourages Islamic banks to find the right marketing strategy (Tabrani et al., 2018). One of the strategies undertaken by several financial institutions is to build long-term relationships with customers so that they remain loyal and do not move to other banks (Clemes et al., 2010).

The relationship between the customer and the bank is limited on the transactional side and has been an interesting issue for many years to be further investigated. It is not only in the service sector that is the main source in establishing good relationships with customers, but consumer confidence in the business systems they do (Iqbal et al., 2018). Islamic banks operate based on non-interest based Islamic sharia in every financial transaction activity. Therefore, Muslim consumers have a tendency to choose Islamic banks because they are based on the religion they profess (Rashid et al., 2009).

Islamic Bank has grown significantly over three decades, especially in Asia, as an alternative to conventional banks (Iqbal et al., 2018). Although the development of Islamic banks is considered less popular and experienced compared to conventional banks (Souiden \& Rani, 2015), Islamic banking is a dynamic financial industry especially in most countries with a majority Muslim population (Suhartanto, 2019) including in Indonesia. Customers will definitely consider factors as their determinant in choosing a bank. Based on this study, it is very possible that conventional bank customers also have a strong desire to move to Islamic banks.

Several previous studies have shown that consumers have the intention to move from conventional banks to Islam which is influenced by religiosity (Saleh et al., 2017; Islam \& Rahman, 2017; Suhartanto, 2019) but not all research results 
state that religion is the only factor that influences how many customers choose their financial institutions (Butt et al., 2018). Based on this gap, the purpose of this study is to examine how the concept of religiosity can influence the intention to switch from conventional banks to Islamic banks.

\section{LITERATURE REVIEW}

\section{The intention of Switching Islamic Bank}

Islamic banks are defined as "A system of banking or banking activities that is consistent with the principles of the Shari'ah (Islamic rulings) and its practical application through the development of Islamic economics" (Belwal \& Al Maqbali, 2018). Islamic banks are not using the interest system on each transaction but with the term profit sharing. Therefore, Muslim consumers in choosing financial institutions are certainly based on the principles set out in Islam, although there are still many Muslim consumers who use conventional banks as financial transactions (Sayani, 2015; Mbawuni \& Nimako, 2018).

Consumer switching behavior in the service marketing literature means that the customer ignores the services provided by one business provider and moves to another service, and this is a very important topic for further research (Kaur et al., 2012). The consumer switching behavior model was first introduced by (Keaveney, 1995) which suggests there are eight key factors in switching, namely price, inconvenience, core service failures, service meeting failures, employee responses to service failures, competition issues, ethical issues, and unintentional factors. One of the causes of the movement of consumers is because they are not satisfied with the services provided by service providers (Clemes et al., 2010; Kaur et al., 2012).

Few previous studies on switching intention in the banking sector prove that there are still antecedents that have not been well studied because they only limit the various relational factors (Chen \& Wang, 2009; Clemes et al., 2010; Kaur et al., 2012). Choi, et al. (2013) in their research stated that there is a role of religiosity towards consumer switching intention because religious differences have behavioral impacts for followers. Therefore, this study explores the antecedents that contribute to the switching intention of Muslim consumers who use conventional banking services to Islamic banking in Indonesia.

\section{Consumer Trust}

Trust is a fundamental construct that is universally accepted by consumers in every transaction and has a dynamic nature (Butt \& Aftab, 2013; Lu et al., 2016). In the banking business, trust has to do with risk vulnerability, the dependence between customers and service providers and involves the confidence of customers and banks about future behavior (Ennew \& Sekhon, 2007). Consumer trust is formed from consumers' experience of perceived services based on bank security and ability and is committed to banks with rules and regulations (Järvinen, 2014). In the perspective of Islamic banks, trust is a symbol of compliance and confidence in Islamic principles that Islamic banks have conducted their business in accordance with Islamic principles (Amin et al., 2013; Sumaedi et al., 2015).

Consumers think that there are still many Islamic banks that are not in accordance with sharia and are the same as conventional banks. To be able to increase consumer confidence, Islamic banks must be able to apply Islamic principles in their business activities and Islamic banks must be in accordance with the reputation of their Islamic compliance (Kaakeh et al., 2019). Ethics and obedience are the main foundations that can shape consumer trust because trust in Islam is a personality trait that must be possessed by Muslims (Nora, 2019). Trust is reflected in the activities of Islamic banks which prohibit the practice of usury in all of their business activities, this is what can build the perspective of trust and attitudes of Muslim consumers in sharia banking practices (Sumaedi et al., 2015).

The level of consumer confidence will increase if consumers trust service providers and if trust decreases, consumers will have the intention to switch to other service providers (Tabrani et al., 2018). Arshad, et al. (2016) found that Muslim consumers have a tendency to switch to Islamic banks because of their belief in sharia principles. Therefore, the hypotheses tested are:

H1: Consumer trust has a significant effect on consumer attitude toward Islamic Bank.

H2: Consumer trust has a significant effect on consumer switching intention to the Islamic Bank.

\section{Consumer Awareness}

Consumer awareness is a concept of perception, one's ability to be able to understand, feel and be aware of an event and object (Aziz \& Chok, 2013). Consumer awareness has an important role in determining consumer intentions to choose an object (Aziz \& Chok, 2013) such as consumer awareness to eat and drink halal (Ambali \& Bakar, 2014), choose Islamic banks (Islam \& Rahman, 2017; Belwal \& Al Maqbali, 2018). Lack of awareness is an important factor for consumers in influencing choices on Islamic banks (Awan \& Khuram, 2011). Consumer perceptions of awareness and understanding of the characteristics, offerings, and benefits typical of Islamic banks, therefore, it is important to serve their interests (Ringim, 2014; Belwal \& Al Maqbali, 2018). 
In spite of the fact that consumers' intention towards sharia banking in the world has increased, consumer awareness still has a lack of awareness of sharia banking products (Sayani \& Miniaoui, 2013). Lack of consumer awareness of Islamic bank products is their main key to the belief that Islamic banks are not in accordance with Islamic principles (Nora, 2019). Therefore, increasing consumer awareness of Islamic bank products can increase understanding of Islamic bank products in accordance with Islamic principles (Kaakeh et al., 2019). Consumer awareness can have a positive influence on consumer attitudes in Islamic banks (Kaakeh et al., 2019) and also in intention to switch to Islamic banks (Saeed \& Binti Abdul Ghani Azmi, 2019). Therefore, the hypotheses tested in this study are:

H3: Consumer awareness has a significant effect on consumer attitude toward Islamic Bank.

H4: Consumer awareness has a significant effect on consumer switching intention to the Islamic Bank.

\section{Religiosity}

The concept of religiosity is a construct that challenges researchers in the field of social science and marketing (Souiden \& Rani, 2015) and is one of the main constructs in measuring religion (Abou-Youssef et al., 2015). Religion is a role model for individuals in close relations with God and closeness with other individuals through beliefs, symbols, and structured rituals (Souiden \& Rani, 2015). Religion shows its followers in the form of a series of beliefs, impressions, and values in interacting with certain communities (Mathras et al., 2016). Religiosity is defined as a person's level of trust and obedience to God accompanied by a commitment to follow the principles adopted through religious practices in everyday life (Mansour \& Diab, 2016; Bakar et al., 2017; Nurhayati \& Hendar, 2019). In other words, religiosity is an indication of someone to choose and consume a product that is in accordance with the principles of their religion (Mathras et al., 2016; Suhartanto et al., 2019).

In Islam, the level of religiosity, in general, can be assessed with the frequency of someone to pray and worship in accordance with the principles of the teachings of Islam (Nurhayati \& Hendar, 2019). In previous literature (AbouYoussef et al., 2015), found significant differences in the level of one's religiosity among Muslims. Some Muslims fully adhere to Islam while others do not. This shows that there is a varying level of individual commitment to Islam that reflects the level of religiosity between a Muslim and others that can be different which results in their behavior.

Previous researchers (Choi et al., 2013) suggested that religious consumers can exhibit different switching behaviors depending on their level of religiosity. Several previous studies have proven that religiosity has a linear and significant relationship to consumer attitudes on Islamic banks (Abou-Youssef et al., 2015), consumer attitudes on Muslim fashion trends_Riptiono, 2019). The other literature also proves that there is a positive relationship between religiosity of consumer intentions on Islamic products such as halal banking products (Butt \& Aftab, 2013), halal products (Nurhayati $\underline{\text { \& Hendar, 2019), }}$, consumer choice toward Islamic banks (Belwal \& Al Maqbali, 2018). Therefore, the hypotheses tested are:

H5: Religiosity has a significant effect on consumer attitude toward Islamic bank.

H6: Religiosity has a significant effect on consumer switching intention to an Islamic bank.

\section{Attitude toward Islamic Bank}

Attitude is a psychological condition of consumers to evaluate feelings when following certain behaviors (Gopi \& Ramayah, 2007; Kaakeh et al., 2019). Attitudes are formed from beliefs that can affect overall consumer intentions (Ajzen, 1991). Behavior intention can reflect two things, namely the intention to behave positively or negatively towards an object (Abou-youssef et al., 2015). The object is a term that has a very broad scope (i.e. products, services, people, financial institutions and brands). The object referred to in this study is the Islamic bank.

Previous empirical research conducted by Kaakeh et al. (2019), concerning Islamic banking, succeeded in proving a strong relationship between the intentions and attitudes of customers and how attitudes can influence intentions. Butt \& Aftab (2013) explained that consumer attitudes towards Islamic banking capture about consumers' perceptions of Islamic banks because Muslim and Non-Muslim consumers have significant perceptual differences towards Islamic banks (Mbawuni \& Nimako, 2018). Muslim consumer attitudes towards an object act as internal predictors that can influence certain intentions and behaviors (Souiden \& Rani, 2015; Riptiono, 2019), including the intention to switch consumers in choosing a suitable bank (Farah, 2017).

Specifically, consumer switching behavior occurs if consumers' attitudes are negative towards a service provider. Consumers evaluate based on their beliefs that can determine their attitudes and influence the intention to switch (Nimako et al., 2014; Farah, 2017). For this reason, the hypothesis proposed in this study is:

H7: Consumer attitude toward Islamic banks has a significant effect on consumer switching intention to an Islamic bank.

\section{METHODOLOGY}

The purpose of this study is to provide further explanation and explore how the antecedents used in this empirical model can influence customer switching intention in Islamic banks. The method used in this study is quantitative research in which data is collected by using a survey with the questionnaire. The location of the study was conducted in central java, 
Indonesia. The populations used in this study are customers of conventional banks managed by the government (BUMN), namely Bank Rakyat Indonesia (BRI), Bank Nasional Indonesia (BNI), and Bank Mandiri. Samples were taken by using purposive sampling technique by visiting the bank directly and giving questionnaires directly to customers who were met by 480 respondents.

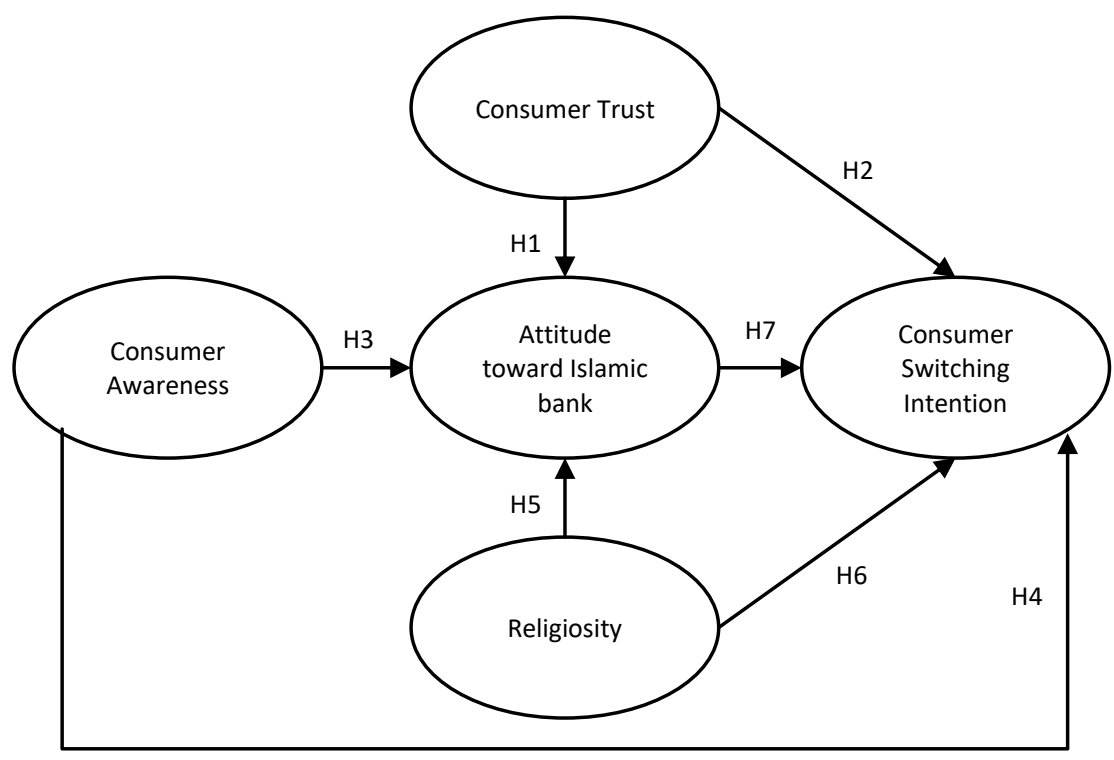

Figure 1: Empirical Model Framework

The sample used in this study refers to Hair et al. (2011) which states that the sample size must be 15-20 observations per variable studied multiplied by the total items in the questionnaire. The items measured are adopted from previous research measurements. The consumer switching intention variable is measured using 3 indicators adopted from (Choi et al., 2013; Saeed \& Binti Abdul Ghani Azmi, 2019). The attitude variable toward Islamic banks was measured using 4 indicators adopted from (Lada et al., 2009; Butt \& Aftab, 2013). Consumer trust variables are measured using 4 indicators adopted from (Amin et al., 2013; Sumaedi et al., 2015; Tabrani et al., 2018). Consumer awareness variables are measured using 6 indicators adopted from (Islam \& Rahman, 2017). Islamic religiosity variables in this study were measured using 5 indicators adapted from (El-Menouar, 2014). The number of samples used in this study was $20 \mathrm{x} 22=$ 440 respondents. All variables were measured using a seven-point Likert scale ranging from (strongly disagree $=$ score 1) to (strongly agree $=$ score 7 ).

\section{RESULTS/FINDINGS}

\section{Descriptive Analysis of Respondent}

Data was collected by distributing questionnaires to 480 respondents distributed at three government conventional banks (BUMN). The three banks BUMN are Bank Rakyat Indonesia (BRI), Bank Nasional Indonesia (BNI), and Bank Mandiri, each bank was taken as many as 160 customers as samples. Based on the results of data collection, the characteristics or profile of 480 respondents can be presented in Table 1 below:

Table 1: Profile of Respondent

\begin{tabular}{|c|c|c|c|c|}
\hline \multirow{2}{*}{ Characteristics } & \multicolumn{3}{|c|}{ Customer of Conventional Bank } & \multirow[t]{2}{*}{ Total } \\
\hline & BRI & BNI & Bank Mandiri & \\
\hline \multicolumn{5}{|l|}{ Gender } \\
\hline - $\quad$ Male & 92 & 88 & 94 & 274 \\
\hline - $\quad$ Female & 68 & 72 & 66 & 206 \\
\hline Total & 160 & 160 & 160 & 480 \\
\hline \multicolumn{5}{|l|}{ Age } \\
\hline - $\quad 17-25$ years & 26 & 22 & 29 & 77 \\
\hline - $26-35$ years & 41 & 44 & 47 & 132 \\
\hline - $36-45$ years & 58 & 66 & 50 & 174 \\
\hline - $\quad>45$ years & 35 & 28 & 34 & 97 \\
\hline Total & 160 & 160 & 160 & 480 \\
\hline \multicolumn{5}{|l|}{ Profession } \\
\hline - $\quad$ Government Employee & 41 & 44 & 37 & 122 \\
\hline - $\quad$ Private Employee & 49 & 47 & 44 & 140 \\
\hline
\end{tabular}




\begin{tabular}{rlllll}
\hline$\bullet$ & Business owner & 53 & 54 & 61 & 168 \\
\hline$\bullet$ & Student & 17 & 15 & 18 & 50 \\
\hline Total & 160 & 160 & 160 & 480 \\
\hline Highest Education Level & & & & \\
\hline$\bullet$ & $<$ High school & 10 & 9 & 60 & 30 \\
\hline$\bullet$ & High school & 56 & 53 & 64 & 169 \\
\hline$\bullet$ & Bachelor/Diploma & 80 & 79 & 25 & 223 \\
\hline$\bullet$ & Post Graduate & 14 & 19 & 160 & 58 \\
\hline Total & 160 & 160 & & 480 \\
\hline
\end{tabular}

Characteristics of respondents by gender are dominated by men are 274 respondents or $57.08 \%$ while female respondents are 206 respondents or $42.92 \%$. The most respondent age is $36-45$ years as much as 174 or $36.25 \%$, followed by respondents aged between 26-35 years as many as 132 or 27, 50\%, and more than 45 years as many as 97 or as much as $20.20 \%$, while the least is the age of respondents $17-25$ years as many as 77 or $16.05 \%$. Next is the profile of respondents by profession which is the most business owner of 168 or $35 \%$. The second is to work as a private employee as many as 140 or 29.16 . The third is 122 government employees or 25.42 . The fourth is a student of 50 or 10.42 . Profile of respondents based on education was dominated by Bachelor / Diploma as many as 223 or $46.46 \%$. Respondents with a high school education were 169 or $35.21 \%$. Postgraduate educated respondents were 58 or $12.08 \%$. Whereas for respondents who were educated under High school only 30 or $6.25 \%$.

\section{Measurement Model}

Table 2 presents the results of testing the instrument validity and reliability. Based on the Cronbach $\alpha$ coefficient, values for consumer trust (0.918), consumer awareness (0.899), Religiosity (0.949), Attitude toward Islamic Bank (0.854), and consumer switching intention (0.825) mean that all constructs provide estimates of internal consistency reliability well. The validity test used in this study is the convergent validity test and the discriminant validity test based on the value of the loading factor, composite reliability (CR) and Average Variance Extracted (AVE). In convergent validity tests, the recommended values (Anderson and Gerbing, 1988) loading factors should be $>0.5$, the AVE should be $>0.5$ and the CR should be $>0.7$. The results show that each loading factor of the indicator is more than 0.5 which is in the range from 0.712 to 0.945 , this means that all constructs (consumer trust, consumer awareness, religiosity, attitude toward Islamic banks, and consumer switching intention) were established (Hair et al., 2011). Meanwhile, AVE in each construct is calculated to assess the validity of discriminant (Hair et al., 2011) with a minimum value of $>0.5$. The result is the AVE value is above 0.5 . For reliability, testing refers to (Hair et al., 2011) which suggests a minimum limit of alpha values is more than 0.7 . The reliability test results stated that all constructs used in this study were declared reliable because Cronbach's alpha was more than the 0.7 limits (Table 2).

Table 2: Measurement Model

\begin{tabular}{|c|c|c|c|c|c|}
\hline Construct/Items & Items & Factor Loading & $\mathrm{A}$ & $\mathrm{CR}$ & AVE \\
\hline \multirow[t]{4}{*}{ Consumer Trust } & CT1 & 0.891 & 0.918 & 0.928 & 0.811 \\
\hline & $\mathrm{CT} 2$ & 0.907 & & & \\
\hline & CT3 & 0.855 & & & \\
\hline & CT4 & 0.813 & & & \\
\hline \multirow[t]{6}{*}{ Consumer Awareness } & CA1 & 0.912 & 0.899 & 0.907 & 0.778 \\
\hline & CA2 & 0.825 & & & \\
\hline & CA3 & 0.835 & & & \\
\hline & CA4 & 0.778 & & & \\
\hline & CA5 & 0.751 & & & \\
\hline & CA6 & 0.877 & & & \\
\hline \multirow[t]{5}{*}{ Religiosity } & R1 & 0.945 & 0.926 & 0.949 & 0.827 \\
\hline & $\mathrm{R} 2$ & 0.933 & & & \\
\hline & R3 & 0.911 & & & \\
\hline & $\mathrm{R} 4$ & 0.939 & & & \\
\hline & R5 & 0.941 & & & \\
\hline \multirow[t]{5}{*}{ Attitude toward Islamic Bank } & ATT1 & 0.786 & 0.854 & 0.899 & 0.707 \\
\hline & ATT2 & 0.809 & & & \\
\hline & ATT3 & 0.712 & & & \\
\hline & ATT4 & 0.809 & & & \\
\hline & ATT5 & 0.723 & & & \\
\hline \multirow[t]{3}{*}{ Consumer Switching Intention } & CSI1 & 0.891 & 0.825 & 0.886 & 0.769 \\
\hline & CSI2 & 0.857 & & & \\
\hline & $\mathrm{CSI} 3$ & 0.929 & & & \\
\hline
\end{tabular}




\section{Test of Hypothesis}

The structural equation model (SEM-AMOS) is used to test the causality relationship and the hypothesis proposed in this study. The results of hypothesis testing are shown in the following table 3 :

Table 3: Test of Hypothesis

\begin{tabular}{llllll}
\hline Hypothesis & Path & Estimate & CR & $p$-value & Result \\
\hline H1 & CT $\rightarrow$ ATT & 0.322 & 7.323 & 0.000 & Supported \\
\hline H2 & CT $\rightarrow$ CSI & 0.071 & 1.445 & 0.281 & Not Supported \\
\hline H3 & CA $\rightarrow$ ATT & 0.304 & 6.112 & 0.001 & Supported \\
\hline H4 & CA $\rightarrow$ CSI & 0.229 & 4.322 & 0.032 & Supported \\
\hline H6 & R $\rightarrow$ ATT & 0.417 & 8.273 & 0.000 & Supported \\
\hline H7 & R $\rightarrow$ CSI & 0.441 & 9.556 & 0.000 & Supported \\
\hline
\end{tabular}

Based on the table above shows the hypothesis testing, it can be seen that from the seven hypotheses tested there were six hypotheses that were declared accepted and only one hypothesis was declared rejected. This means that in this study shows that consumer trust can provide a positive and significant effect on attitude toward Islamic banks (CR: 7,323, pvalue: 0,000 , estimate: 0.322 ) but consumer trust is not able to influence consumer switching intention on Islamic bank (CR: 1.445, P-value: 0.281, estimate: 0.071). As for the relationship between consumer awareness towards attitude toward Islamic banks is positive and significant (CR: 6.112, p-value: 0.000, estimate: 0.304 ) and can also increase consumer switching intention in Islamic banks (CR: 4.332, p-value: 0.032, estimate: 0.229). In addition, religiosity can also have a positive and significant impact on attitude toward Islamic banks (CR: 8,273, p-value: 0,000, estimate: 0.417) or on consumer switching intention (CR: 9,556, p-value: 0,000, estimate: 0.441). Meanwhile, attitude toward Islamic banks was also proven to have a positive and significant impact on consumer switching intention (CR: 5.028, p-value: 0.012 , estimate: 0.213 ).

\section{DISCUSSION / ANALYSIS}

In testing the first hypothesis (H1) declared acceptable, it means that consumer trust in Islamic banks can have a positive and significant influence on consumer attitude toward Islamic banks. This means that consumer confidence in Islamic banks can form positive consumer attitudes towards Islamic banks, and the magnitude of the effect of consumer trust on attitudes toward Islamic banks is 0.322 or $32.2 \%$. This result is in line with several previous studies conducted by (Sumaedi et al., 2015; Ghoochani et al., 2018; Tabrani et al., 2018). While testing the second hypothesis (H2) was declared rejected, consumer trust was not proven to affect the consumer switching intention. This means that consumer confidence in Islamic banks is not able to have a significant impact on their intention to switch to Islamic banks. These results are different from previous studies conducted by (Arshad et al., 2016; Liang et al., 2018).

The third hypothesis testing (H3) is stated accepted, meaning that consumer awareness can be an antecedent for attitude toward Islamic banks that are able to give an effect of 0.304 or $30.4 \%$. This means that, the higher consumer awareness on Islamic banks, the better the attitude of consumers in Islamic banks. The results of this study are in line with several previous studies conducted by (Islam \& Rahman, 2017; Kaakeh et al., 2019). And the test results on the fourth hypothesis (H4) prove that consumer awareness can provide a positive and significant influence on consumer switching intention on the Islamic Bank and the amount of influence is 0.229 or $22.9 \%$. This means that the higher consumer awareness of Islamic banks will increase the consumer's intention to move from conventional banks to Islamic banks. The results of this study are the same as some previous studies conducted by (Aziz \& Chok, 2013; Islam \& Rahman, 2017; Bashir et al., 2019; Nurhayati \& Hendar, 2019).

The results of the fifth hypothesis testing (H5) tested the effect of religiosity on attitude toward Islamic banks, the results were stated that the hypothesis was accepted and the magnitude of the effect was 0.417 or $41.7 \%$. This means that the higher level of consumer religiosity will have an impact on increasing consumer attitude toward Islamic banks. The results of this study are in accordance with several previous studies conducted by (Abou-Youssef et al., 2015; Souiden \& Rani, 2015; Riptiono, 2019). The sixth hypothesis testing (H6) proved that religiosity had a positive and significant impact on consumer switching intention. This means that consumers with a high level of religiosity will have a great intention to move to Islamic banks and be able to give an influence of 0.441 or $44.1 \%$. The results of the study are in line with several previous studies conducted by (Amin et al., 2013; Choi et al., 2013; Nurhayati \& Hendar, 2019).

Finally, the results of the seventh hypothesis testing (H7) revealed that consumer attitude toward Islamic banks had a positive and significant effect on consumer switching intention to Islamic banks with a magnitude of influence of 0.213 or $21.3 \%$. This means that increasingly positive consumer attitudes are good predictors in increasing consumer switching intention. Some previous studies prove that consumer attitude is an antecedent of consumer intention (Souiden \& Rani, 2015; Farah, 2017; Bashir et al., 2019). 


\section{CONCLUSION}

The findings of this study indicate that Muslim consumers who are still customers in conventional banks actually have the intention to switch toward Islamic banks. Some factors that can increase their intention to move to Islamic banks are consumer awareness of Islamic banks that are in accordance with Islamic principles, such as not applying Riba. Consumer awareness can have a positive and significant influence on attitude toward Islamic banks and also on consumer switching intentions to Islamic banks. Next, the religiosity factor is also proven to be able to increase positive consumer attitudes on Islamic banks so that they can have an impact on consumer switching intention. Different results on consumer trust can only affect consumer attitudes on Islamic banks but cannot contribute to consumers to increase intention to move to Islamic banks. One possibility is that consumers assume that Islamic banks do not really practice Islamic banking (Butt et al., 2018), this is what makes consumers hesitant and do not intend to switch to Islamic banks.

\section{LIMITATION AND STUDY FORWARD}

In this study there are limitations, namely, the sample used is only conventional government-owned bank customers in Central Java. Therefore, future research can expand the area and other types of banks will be possible to obtain different results.

\section{ACKNOWLEDGEMENT}

We would like to thank for the support from Sekolah Tinggi Ilmu Ekonomi Putra Bangsa and all of the teams of HSSR.

\section{AUTHORS CONTRIBUTION}

Author 1: Conceptualization, Methodology, Formal analysis, Writing, and Editing Draft.

Author 2: Supervisor.

Author 3: Supervisor and Assist in the data processing.

\section{REFERENCES}

1. Abou-Youssef, M. M. H., Kortam, W., Abou-Aish, E., \& El-Bassiouny, N. (2015). Effects of Religiosity on Consumer Attitudes Toward Islamic Banking in Egypt. International Journal of Bank Marketing,33(6), 786807. https://doi.org/10.1108/IJBM-02-2015-0024

2. Ajzen, I. (1991). The Theory of Planned Behavior. Organizational Behavior and Human Decision Processes. SS50(2), 179-211. https://doi.org/10.1016/0749-5978(91)90020-T

3. Ambali, A. R., \&Bakar, A. N. (2014). People 's Awareness on Halal Foods and Products: Potential Issues for $\begin{array}{lllll}\text { Policy-Makers. Procedia-Social and Behavioral Sciences, } & \text { 121(3), 3-25. }\end{array}$ https://doi.org/10.1016/j.sbspro.2014.01.1104

4. Amin, M., Isa, Z., \& Fontaine, R. (2013). Islamic Banks: Contrasting The Drivers of Customer Satisfaction on Image, Islamic Banks Contrasting the Drivers of Customer. International Journal of Bank, 31(2), 79-97. https://doi.org/10.1108/02652321311298627

5. Anderson, J.C., Gerbing, D.W., 1988. Structural Equation Modelling in Practice: A Review and Recommended Two-Step Approach. Psychol. Bull. 103 (3), 411-423. https://doi.org/10.1037/0033-2909.103.3.411

6. Arshad, T., Zahra, R., \& Draz, U. (2016). Impact of Customer Satisfaction on Image, Trust, Loyalty and The Customer Switching Behavior in Conventional and Islamic Banking: Evidence from Pakistan. American Journal of Business and Society, 1(3), 154-165.

7. Awan, H. M., \& Khuram, S. S. (2011). Customer's Criteria for Selecting an Islamic Bank: Evidence from Pakistan. Journal of Islamic Marketing, 2(1), 14-27. https://doi.org/10.1108/17590831111115213

8. Aziz, Y. A., \& Chok, N. V. (2013). The Role of Halal Awareness, Halal Certification, And Marketing Components in Determining Halal Purchase Intention Among Non-Muslims in Malaysia: A Structural Equation Modelling Approach. Journal of International Food and Agribusiness Marketing,25(1), 1-23. https://doi.org/10.1080/08974438.2013.723997

9. Bakar, J. A., Clemes, M. D., \& Bicknell, K. (2017). A Comprehensive Hierarchical Model of Retail Banking. International Journal of Bank Marketing, 35(4), 662-684. https://doi.org/10.1108/IJBM-03-2016-0041

10. Bashir, A. M., Bayat, A., Olutuase, S. O., \& Abdul Latiff, Z. A. (2019). Factors affecting consumers' intention towards purchasing halal food in South Africa: a structural equation modelling. Journal of Food Products Marketing, 25(1), 26-48. https://doi.org/10.1080/10454446.2018.1452813

11. Belwal, R., \& Al Maqbali, A. (2018). A Study of Customers' Perception of Islamic Banking in Oman. Journal of Islamic Marketing,10(1), 150-167. https://doi.org/10.1108/JIMA-02-2016-0008

12. Butt, I., Ahmad, N., Naveed, A., \& Ahmed, Z. (2018). Determinants of Low Adoption of Islamic Banking in Pakistan, Journal of Islamic Marketing,9(3), 655-672. https://doi.org/10.1108/JIMA-01-2017-0002

13. Butt, M. M., \& Aftab, M. (2013). Incorporating Attitude Towards Halal Banking in an Integrated Service Quality, Satisfaction, Trust and Loyalty Model in Online Islamic Banking Context. International Journal of Banks Marketing, 31(1), 6-23. https://doi.org/10.1108/02652321311292029 
14. Chen, M., \& Wang, L. (2009). The Moderating Role of Switching Barriers on Customer Loyalty in the Life Insurance Industry. The Service Industries Journal, 29(8), 1105-1123. https://doi.org/10.1080/02642060902764574

15. Choi, Y., Paulraj, A., \& Shin, J. (2013). Religion or Religiosity: Which is the Culprit for Consumer Switching Behavior? Journal of International Consumer Marketing, 25(4), 262-280.

16. Clemes, M. D., Gan, C., \& Zhang, D. (2010). Customer Switching Behaviour in the Chinese Retail Banking Industry. International Journal of Bank Marketing, 28(7), 519-546. https://doi.org/10.1108/02652321011085185

17. El-Menouar, Y. (2014). The Five Dimensions of Muslim Religiosity. Results of an Empirical Study. Methods, Data, Analyses, 8(1), 26. https://doi.org/10.12758/mda.2014.003

18. Ennew, C., \& Sekhon, H. (2007). Measuring Trust in Financial Services: The Trust Index. Consumer Policy Review, 17(2), 62-68.

19. Farah, M. F. (2017). Application of The Theory of Planned Behavior to Customer Switching Intentions in The Context of Bank Consolidations. International Journal of Bank Marketing, 35(1), 147-172. https://doi.org/10.1108/IJBM-01-2016-0003

20. Ghoochani, O. M., Torabi, R., Hojjati, M., Ghanian, M., \& Kitterlin, M. (2018). Factors Influencing Iranian Consumers' Attitudes Toward Fast-Food Consumption. British Food Journal, 120(2), 409-423. https://doi.org/10.1108/BFJ-12-2016-0612

21. Gopi, M., \& Ramayah, T. (2007). Applicability of Theory of Planned Behavior in Predicting Intention to Trade Online. International Journal of Emerging Markets, 2(4), 348-360. https://doi.org/10.1108/17468800710824509

22. Hair, J. F., Ringle, C. M., \& Sarstedt, M. (2011). PLS-SEM: Indeed a Silver Bullet. Journal of Marketing theory and Practice, 19(2), 139-152. https://doi.org/10.2753/MTP1069-6679190202

23. Iqbal, M., Nisha, N., \& Rashid, M. (2018). Bank Selection Criteria and Satisfaction of Retail Customers of Islamic Banks in Bangladesh. International Journal of Bank Marketing, 36(5), 931-946. https://doi.org/10.1108/IJBM-01-2017-0007

24. Islam, J. U., \& Rahman, Z. (2017). Awareness and Willingness Towards Islamic Banking among Muslims: An Indian Perspective. International Journal of Islamic and Middle Eastern Finance and Management, 10(1), 92101. https://doi.org/10.1108/IMEFM-01-2016-0017

25. Järvinen,R. A. (2014). Consumer trust in banking relationships in Europe. International Journal of Bank Marketing,32(6), 551-556. https://doi.org/10.1108/IJBM-08-2013-0086

26. Kaakeh, A., Hassan, M. K., \& Almazor, S. F. V. H. (2019). Factors Affecting Customers' Attitude Towards Islamic Banking in UAE. International Journal of Emerging Markets.14(4), 668-688. https://doi.org/10.1108/IJOEM-11-2017-0502

27. Kaur, G., Sharma, R. D., \& Mahajan, N. (2012). Exploring Customer Switching Intentions through Relationship Marketing Paradigm. International Journal of Bank Marketing, 30(4), 280-302. https://doi.org/10.1108/02652321211236914

28. Keaveney, S. M. (1995). Customer Switching Behavior in Service Industries: an Exploratory Study. Journal of Marketing, 59(2), 71-82. https://doi.org/10.1177/002224299505900206

29. Lada, S., Tanakinjal, G. H., \& Amin, H. (2009). Predicting Intention to Choose Halal Products Using Theory of Reasoned Action. International Journal of Islamic and Middle Eastern Finance and Management, 2(1), 66-76. https://doi.org/10.1108/17538390910946276

30. Lu, B., Fan, W., \& Zhou, M. (2016). Social Presence, Trust, and Social Commerce Purchase Intention: An Empirical Research. Computers in Human Behavior, 56, 225-237. https://doi.org/10.1016/j.chb.2015.11.057

31. Mansour, I. H. F., \& Diab, Dalia M. E. (2016). The Relationship Between Celebrities' Credibility and Advertising Effectiveness: The Mediation Role of Religiosity. Journal of Islamic Marketing,7(2), 148-166. https://doi.org/10.1108/JIMA-05-2013-0036

32. Mathras, D., Cohen, A. B., Mandel, N., \& Mick, D. G. (2016). The Effects of Religion on Consumer Behavior: a Conceptual Framework and Research Agenda. Journal of Consumer Psychology, 26(2), 298-311. https://doi.org/10.1016/j.jcps.2015.08.001

33. Mbawuni, J., \& Nimako, S. G. (2018). Muslim and Non-Muslim Consumers' Perception Towards Introduction of Islamic Banking in Ghana. Journal of Islamic Accounting and Business Research, 9(3), 353-377. https://doi.org/10.1108/JIABR-04-2016-0050

34. Nimako, S. G., Ntim, B. A., \& Mensah, A. F. (2014). Effect of Mobile Number Portability Adoption on Consumer Switching Intention. International Journal of Marketing Studies, 6(2), 117-134. https://doi.org/10.5539/ijms.v6n2p117

35. Nora, L. (2019). Trust, Commitment, and Customer Knowledge: Clarifying Relational Commitments and Linking Them to Repurchasing Intentions. Management Decision, 57(11), 3134-3158. https://doi.org/10.1108/MD-10-2017-0923

36. Nurhayati, T., \& Hendar, H. (2019). Personal intrinsic religiosity and product knowledge on halal product purchase intention: role of halal product awareness. Journal of Islamic Marketing. https://doi.org/10.1108/JIMA-11-2018-0220 
37. Rashid, M., Hasan, M. K., \& Ahmad, A. U.F. (2009). Quality Perception of the Customers Towards Domestic Islamic Banks in Bangladesh. Journal of Islamic Economics, Banking and Finance, 5(1), 109-131.

38. Ringim, K. J. (2014). Perception of Nigerian Muslim Account Holders in Conventional Banks toward Islamic Banking Products. International Journal of Islamic and Middle Eastern Finance and Management,7(3), 288305. https://doi.org/10.1108/IMEFM-04-2013-0045

39. Riptiono, S. (2019). Does Islamic religiosity influence female muslim fashion trend purchase intention? an extended of theory of planned behavior. Iqtishadia: Jurnal Kajian Ekonomi dan Bisnis Islam,12(1), 16-36. https://doi.org/10.21043/iqtishadia.v12i1.4384

40. Saeed, M., \& Binti Abdul Ghani Azmi, I. (2019). The Nexus Between Customer Equity and Brand Switching Behaviour of Millennial Muslim Consumers. South Asian Journal of Business Studies, 8(1), 62-80. https://doi.org/10.1108/SAJBS-04-2018-0046

41. Saleh, M. A., Quazi, A., Keating, B., \& Gaur, S. S. (2017). Quality and Image of Banking Services: A Comparative study of conventional and islamic banks. International Journal of Bank Marketing, 35(6), 878902. https://doi.org/10.1108/IJBM-08-2016-0111

42. Sayani,H. (2015). Customer satisfaction and loyalty in the United Arab Emirates banking industry. International Journal of Bank Marketing. 33(3), 351-375. https://doi.org/10.1108/IJBM-12-2013-0148

43. Sayani, H., \& Miniaoui, H. (2013). Determinants of bank selection in the United Arab Emirates. International Journal of Bank Marketing. 31(3), 206-228. https://doi.org/10.1108/02652321311315302

44. Souiden, N., \& Rani, M. (2015). Consumer attitudes and purchase intentions toward Islamic banks: the influence of religiosity. International Journal of Banking Marketing, 33(2), $143-161$. https://doi.org/10.1108/IJBM-10-2013-0115

45. Suhartanto, D. (2019). Predicting behavioural intention toward Islamic bank: a multi-group analysis approach. Journal of Islamic Marketing. https://doi.org/10.1108/JIMA-02-2018-0041.

46. Suhartanto, D., Gan, C., Sarah, I. S., \& Setiawan, S. (2019). Loyalty towards Islamic banking: service quality, emotional or religious driven?.Journal of Islamic Marketing. https://doi.org/10.1108/JIMA-01-2018-0007

47. Sumaedi, S., Juniarti, R. P., \& Bakti, I. G. M. Y. (2015). Understanding trust \& commitment of individual saving customers in Islamic banking. Journal of Islamic Marketing, 6(3), 406-428. https://doi.org/10.1108/JIMA-06-2013-0045

48. Tabrani, M., Amin, M., \& Nizam, A. (2018). Trust, commitment, customer intimacy and customer loyalty in Islamic banking relationships. International Journal of Bank Marketing,36(5), 823-848. https://doi.org/10.1108/IJBM-03-2017-0054 